The Legal Basis for the Exercise of Jurisdiction by the International Criminal Court and the Preparatory Work of the Rome Statute (II)

Yoshiaki KITANO

Vol. 17, No. 1 (September 2018) 


\title{
The Legal Basis for the Exercise of Jurisdiction by the International Criminal Court and the Preparatory Work of the Rome Statute (II)
}

\author{
Yoshiaki KITANO
}

\section{Chapter 2 Existing Theories}

As already mentioned in the previous chapter, the legal basis for the exercise of jurisdiction by the ICC has been discussed by a number of scholars in international law. This chapter aims to summarise the existing theories. Due to limitations of space, however, only scholars who provide sufficiently clear theoretical frameworks will be mentioned here.

\section{Section 1 Exercise of State Jurisdiction through the ICC}

It is notable that many of the scholars who have written on this topic regard (part of) the ICC's exercise of jurisdiction as the exercise, through the ICC, of jurisdiction which accepting states originally possess. For example, Mahmoud Cherif Bassiouni states as follows:

[W]henever a crime is committed in the territory of a state, the state can prosecute the perpetrator, even in the case where that person is not a national of that state. [...] Consequently, every state has the right, in conformity with its constitutional norms, to transfer that jurisdiction [...] to an international judicial body ${ }^{23}$.

Also, Michael Scharf expresses the same view of the ICC's exercise of jurisdiction using various terms like "conferral", "delegation" and "collective exercise" of state

23 M. Cherif Bassiouni, "Note explicative sur le statut de la Cour pénale internationale (CPI)," Revue internationale de droit pénal, Vol. 71, Nos. 1-2 (2000), p. 8. The original French text reads as follows:

[C]haque fois qu'un crime est commis sur le territoire d'un Etat donné, ce dernier peut poursuivre celui qui l'a commis, y compris dans le cas où cette personne ne serait pas l'un de ces ressortissants. [...] Par conséquent, tout Etat a le droit, conformément à ses normes constitutionnelles, de transférer cette compétence $[\ldots]$ vers un organe international de jugement. 
Journal of International Relations and Comparative Culture Vol. 17 No. 1

jurisdiction ${ }^{24,25}$.

In the following subsections 1 to 4 , the scholars who think it possible to exercise state jurisdiction through the ICC will be categorised according to their opinions on when and what kind of state jurisdiction is exercised through the ICC, and the arguments in each category analysed systematically. Conversely, in subsection 5, the counter-arguments which other scholars have presented to deny the possibility of such exercise of state jurisdiction will be examined. Finally, this section will conclude with a concise summary given in subsection 6 .

\section{Arguments for the Exercise of Territorial Jurisdiction through the ICC}

Firstly, many of the scholars who consider only the cases in which the territorial state has accepted the ICC's exercise of jurisdiction (hereinafter referred to as "the cases of the territorial state's acceptance") regard the ICC's exercise of jurisdiction in these cases as the exercise of territorial jurisdiction of accepting states through the ICC. To support this view, they explore the following two issues.

The first is whether states can exercise, under customary international law, territorial jurisdiction over the crimes with respect to which the ICC has jurisdiction in accordance with the Statute ${ }^{26}$. Harmen Van Der Wilt answers affirmatively, referring to the US Supreme Court's decision on the Schooner Exchange v. McFaddon and others $(1812)^{27,28}$.

The second issue is whether territorial jurisdiction of states can be exercised, under customary international law, through courts, including the ICC, other than their own domestic ones when they give consent (including consent given in accordance with Article 25 of the UN Charter ${ }^{29}$ ). Bassiouni cites the European Convention on the Transfer

24 Michael P. Scharf, "The ICC's Jurisdiction over the Nationals of Non-Party States: A Critique of the U.S. Position," Law and Contemporary Problems, Vol. 64, No. 1 (2001), pp. 103, 108, 110, 116, 117.

25 Regarding the legal entity which exercises jurisdiction which accepting states originally possess, terms like "conferral" and "delegation" seem to imply that the ICC exercises such jurisdiction, while terms like "collective exercise" could indicate that accepting states do it themselves. In any case, there does not seem to be any scholar who has offered detailed explanations on the usage of these terms. The use of the phrase "the exercise of state jurisdiction through the ICC" in this paper is not based on any presumption about this issue.

26 See note 8 .

27 The relevant part of the decision reads as follows:

The jurisdiction of courts is a branch of that which is possessed by the nation as an independent sovereign power. The jurisdiction of the nation, within its own territory, is necessarily exclusive and absolute; it is susceptible of no limitation, not imposed by itself. Any restriction upon it, deriving validity from an external source, would imply a diminution of its sovereignty, to the extent of the restriction, and an investment of that sovereignty, to the same extent, in that power which could impose such restriction. All exceptions, therefore, to the full and complete power of a nation, within its own territories, must be traced up to the consent of the nation itself. They can flow from no other legitimate source. (U.S., Vol. 11 (Cranch, Vol. 7), p. 136)

28 Van Der Wilt, supra note 5, p. 98. 
The Legal Basis for the Exercise of Jurisdiction

of Proceedings in Criminal Matters (hereinafter referred to as "the ECTPCM") as a preceding mechanism of such exercise of territorial jurisdiction ${ }^{30}$. Moreover, Dapo Akande cites many treaties and courts like the Convention for the Suppression of Unlawful Seizure of Aircraft (hereinafter referred to as "the Hague Hijacking Convention")" ${ }^{31}$, the International Criminal Tribunal for the former Yugoslavia (hereinafter referred to as "the ICTY") ${ }^{32}$, and the International Criminal Tribunal for Rwanda (hereinafter referred to as "the ICTR" $)^{33}$ as preceding mechanisms of such exercise of state jurisdiction, though he does not clearly show his understanding of each of these mechanisms ${ }^{34,35}$. On the contrary, Frédéric Mégret, instead of mentioning preceding mechanisms like Bassiouni and Akande, argues that "states may exercise their sovereign jurisdiction in whatever way they want, as long as they remain within the bounds of what is meant by territorial jurisdiction, namely, as long as they exercise their jurisdiction over their territory, no more, no less", and thinks of the exercise of territorial jurisdiction through the ICC as a way to exercise this kind of state jurisdiction legally ${ }^{36}$.

29 Article 25 of the UN Charter stipulates the following:

The Members of the United Nations agree to accept and carry out the decisions of the Security Council in accordance with the present Charter.

30 Bassiouni, supra note 23, pp. 8-9.

31 See Article 7 of the Hague Hijacking Convention, which stipulates the following:

The Contracting State in the territory of which the alleged offender is found shall, if it does not extradite him, be obliged, without exception whatsoever and whether or not the offence was committed in its territory, to submit the case to its competent authorities for the purpose of prosecution. Those authorities shall take their decision in the same manner as in the case of any ordinary offence of a serious nature under the law of that State.

Referring to this article, Akande claims that the reason why the state in the territory of which an alleged offender is found (hereinafter referred to as "the custodial state") can prosecute him legally is that the criminal jurisdiction of another state is exercised through the domestic courts of the custodial state. Akande, supra note 5 ("The Jurisdiction"), pp. 623-624.

32 The unabridged official name of the ICTY is "the International Tribunal for the Prosecution of Persons Responsible for Serious Violations of International Humanitarian Law Committed in the Territory of the Former Yugoslavia since 1991". It was established in May 1993 by the UN Security Council Resolution 827 (1993).

33 The unabridged official name of the ICTR is "the International Tribunal for the Prosecution of Persons Responsible for Genocide and Other Serious Violations of International Humanitarian Law Committed in the Territory of Rwanda and Rwandan Citizens Responsible for Genocide and Other Such Violations Committed in the Territory of Neighbouring States, between 1 January 1994 and 31 December 1994". It was established in November 1994 by the UN Security Council Resolution 955 (1994).

34 In particular, Akande's understanding of the ICTY seems questionable, because he asserts that territorial jurisdiction is exercised through this court, even in the cases where the Federal Republic of Yugoslavia (hereinafter referred to as "the FRY") is both the nationality state and territorial state, in spite of his presumption that this state was not a member of the UN during the period from 1992 to 2000. Ibid., pp. 628-630.

35 Ibid., pp. 621-634. 
Journal of International Relations and Comparative Culture Vol. 17 No. 1

\section{Arguments for the Concurrent Exercise of Territorial and Universal Jurisdictions through the ICC}

Secondly, among the scholars who consider only the cases of the territorial state's acceptance, Scharf and Damir Arnaut regard the ICC's exercise of jurisdiction in these cases as the concurrent exercise of territorial and universal jurisdictions of accepting states through the ICC. To support this view, they explore the following two issues.

The first is whether states can exercise, under customary international law, territorial and universal jurisdictions over the crimes with respect to which the ICC has jurisdiction in accordance with the Statute. Scharf argues that they can, referring to the status of ratification of the First Additional Protocol to the Geneva Conventions of 1949 (hereinafter referred to as "the AP1") ${ }^{37}$ and various other pieces of evidence in respect of universal jurisdiction of states $^{38}$.

The second issue is whether territorial and universal jurisdictions of states can be exercised, under customary international law, through courts, including the ICC, other than their own domestic ones when they give consent (including consent given in accordance with Article 25 of the UN Charter). Scharf cites the ECTPCM and International Military Tribunal (hereinafter referred to as "the IMT") ${ }^{39}$ as preceding mechanisms of such exercise of territorial jurisdiction, and cites the IMT, ICTY and ICTR as those of universal jurisdiction ${ }^{40}$. Moreover, Arnaut cites the ICTY and ICTR as preceding mechanisms of such exercise of state jurisdiction, without describing what

36 Frédéric Mégret, "Epilogue to an Endless Debate: The International Criminal Court's Third Party Jurisdiction and the Looming Revolution of International Law," European Journal of International Law, Vol. 12, No. 2 (2001), pp. 251-253.

37 The unabridged official name of the AP1 is "the Protocol Additional to the Geneva Conventions of 12 August 1949, and relating to the Protection of Victims of International Armed Conflicts (Protocol I)".

38 Scharf, supra note 24 , pp. 79-103. Universal jurisdiction of states has been a hotly-debated topic in recent years, but this paper does not elaborate on it at length.

39 The relevant part of the judgment of the IMT (1946), which Scharf and other scholars refer to, reads as follows:

The making of the Charter [ $=$ the Charter of the IMT] was the exercise of the sovereign legislative power by the countries to which the German Reich unconditionally surrendered; and the undoubted right of these countries to legislate for the occupied territories has been recognized by the civilized world. The Charter is not an arbitrary exercise of power on the part of the victorious nations, but in the view of the Tribunal, as will be shown, it is the expression of international law existing at the time of its creation; and to that extent is itself a contribution to international law.

The Signatory Powers created this Tribunal, defined the law it was to administer, and made regulations for the proper conduct of the Trial. In doing so, they have done together what any one of them might have done singly; for it is not to be doubted that any nation has the right thus to set up special courts to administer law. With regard to the constitution of the Court, all that the defendants are entitled to ask is to receive a fair trial on the facts and law.

(Trial of the Major War Criminals before the International Military Tribunal, Vol. 22, p. 461)

40 Scharf, supra note 24, pp. 103-110, 113-116. 
The Legal Basis for the Exercise of Jurisdiction

kinds of state jurisdiction are exercised through each of these courts ${ }^{41}$.

\section{Arguments for the Exercise of Territorial or Active Personality Jurisdiction through the ICC depending on the Accepting State}

Thirdly, many of the scholars who consider not only the cases of the territorial state's acceptance but also the ones in which the nationality state has accepted the ICC's exercise of jurisdiction (hereinafter referred to as "the cases of the nationality state's acceptance") regard the ICC's exercise of jurisdiction as the exercise of territorial jurisdiction of accepting states through the ICC in relation to former cases, and as the exercise of active personality jurisdiction of such states through it in relation to latter ones. To support this view, they explore the following two issues.

The first is whether states can exercise, under customary international law, territorial and active personality jurisdictions over the crimes with respect to which the ICC has jurisdiction in accordance with the Statute. Sharon Williams states that this is possible, referring to the International Convention for the Suppression of Terrorist Bombings (hereinafter referred to as "the Terrorist Bombings Convention") ${ }^{42,43}$.

The second issue is whether territorial and active personality jurisdictions of states can be exercised, under customary international law, through courts, including the ICC, other than their own domestic ones when they give consent (including consent given in accordance with Article 25 of the UN Charter). Gerhard Hafner, Kristen Boon, Anne Rübesame and Jonathan Huston cite the European Court of Human Rights (hereinafter referred to as "the ECHR") as a preceding mechanism of such exercise of state jurisdiction, without describing what kinds of state jurisdiction are exercised through this court $^{44}$. Moreover, Diane Orentlicher cites the IMT as a mechanism providing the

41 Damir Arnaut, "When in Rome...? The International Criminal Court and Avenues for U.S. Participation," Virginia Journal of International Law, Vol. 43, No. 2 (2003), pp. 551-553.

42 See Article 6, paragraph 1, of the Terrorist Bombings Convention, which stipulates the following:

Each State Party shall take such measures as may be necessary to establish its jurisdiction over the offences set forth in article 2 when:

(a) The offence is committed in the territory of that State; or

(b) The offence is committed on board a vessel flying the flag of that State or an aircraft which is registered under the laws of that State at the time the offence is committed; or

(c) The offence is committed by a national of that State.

43 Sharon A. Williams, "Article 12," in Otto Triffterer (ed.), Commentary on the Rome Statute of the International Criminal Court: Observers' Notes, Article by Article (Nomos Verlagsgesellschaft, 1999), pp. 339-341. It should be pointed out, however, that, relating to the cases of the nationality state's acceptance, she invokes active personality jurisdiction of states but does not clearly contend that it is exercised through the ICC. Ibid., pp. 340-341. See also, Cryer, Friman, Robinson and Wilmshurst, supra note 5, pp. 167, 172; Schabas, supra note 5 ("The International Criminal Court"), pp. 354-355; Dominik Zimmerman (revised by Mark Klamberg), "Article 12," in Mark Klamberg (ed.), supra note 5, pp. 171-172. 
Journal of International Relations and Comparative Culture Vol. 17 No. 1

precedents of such exercise of state jurisdiction in general, claiming that while the judgement of the $\mathrm{IMT}^{45}$ "focuses upon the territorial basis of jurisdiction deriving from the Four Powers' status as occupation forces, the basic principle that States can 'do together' jurisdictionally 'what any one of them might have done singly' would be equally relevant with respect to any basis for exercising national jurisdiction established in international law" ${ }^{\prime 46}$. Likewise, Markus Wagner views the IMT as a mechanism providing the precedents of such exercise of state jurisdiction in general, while he does not comment on what kind of state jurisdiction was exercised through this court ${ }^{47}$. Furthermore, Gennady Danilenko cites, in addition to the IMT, the international penal tribunals that are mentioned in the Convention on the Prevention and Punishment of the Crime of Genocide (hereinafter referred to as "the Genocide Convention") and the International Convention on the Suppression and Punishment of the Crime of Apartheid (hereinafter referred to as "the Apartheid Convention") ${ }^{48}$ as preceding mechanisms of such exercise of state jurisdiction, without describing what kinds of state jurisdiction are exercised through each of these courts ${ }^{49}$.

44 Gerhard Hafner, Kristen Boon, Anne Rübesame and Jonathan Huston, "A Response to the American View as Presented by Ruth Wedgwood," European Journal of International Law, Vol. 10, No. 1 (1999), p. 117.

45 See note 39. Roger O'Keefe similarly states that "states have no greater right to do together what none of them is permitted by international law to do alone", though he does not make explicit reference to the judgement of the IMT. O'Keefe, supra note 5, p. 541.

46 Diane F. Orentlicher, "Politics by Other Means: The Law of the International Criminal Court," Cornell International Law Journal, Vol. 32, Iss. 3 (1999), p. 493. Moreover, Robert Cryer, Håkan Friman, Darryl Robinson and Elizabeth Wilmshurst, referring to the same judgement, claim that "international law does not preclude States from acting collectively in delegating to an international court the jurisdiction which they would be entitled to exercise themselves, and there is no requirement for a positive rule of international law allowing States to exercise their jurisdiction collectively in this manner". Cryer, Friman, Robinson and Wilmshurst, supra note 5, p. 172.

47 Wagner, supra note 5, pp. 488-489. He also mentions the Hague Hijacking Convention (see note 31) and other similar treaties, but it is not clear whether he views these treaties as preceding mechanisms similar to the IMT. Ibid., p. 488.

48 See Article 6 of the Genocide Convention and Article 5 of the Apartheid Convention, which refer similarly to an "international penal tribunal". For example, the former article stipulates the following:

Persons charged with genocide or any of the other acts enumerated in article 3 shall be tried by a competent tribunal of the State in the territory of which the act was committed, or by such international penal tribunal as may have jurisdiction with respect to those Contracting Parties which shall have accepted its jurisdiction.

49 Gennady M. Danilenko, "ICC Statute and Third States," in Antonio Cassese, Paola Gaeta and John R. W. D. Jones (eds.), The Rome Statute of the International Criminal Court: A Commentary (Oxford University Press, 2002), pp. 1881-1882. 
The Legal Basis for the Exercise of Jurisdiction

\section{Arguments for the Exercise of Universal Jurisdiction through the ICC in All Cases}

Lastly, among the scholars who consider, in addition to the cases of the territorial state's or nationality state's acceptance, the ones in which the UN Security Council acting under Chapter VII of the UN Charter refers a situation to the Prosecutor (hereinafter referred to as "the cases of the Security Council's referral"), Jordan Paust regards the ICC's exercise of jurisdiction in all cases as the exercise of universal jurisdiction of accepting states through the ICC. To support this view, he explores the following two issues.

The first is whether universal jurisdiction of states can be exercised, under customary international law, through courts, including the ICC, other than their own domestic ones when they give consent (including consent given in accordance with Article 25 of the UN Charter). Paust asserts that "[n]o known treaty or rule of customary international law precludes such an arrangement for the exercise of jurisdiction", while additionally citing the IMT as a preceding mechanism of such exercise of universal jurisdiction ${ }^{50}$.

The second issue is whether Article 12 of the Statute provides for the obligation of accepting states to acquiesce in the ICC's exercise of jurisdiction as the exercise of their universal jurisdiction through the ICC, and whether an acceptance in accordance with the same article constitutes consent to the creation of the above-mentioned obligation. Paust interprets Article 12 in accordance with Article 31 of the VCLT $^{51}$ and argues that it does, contending that the Preamble of the Statute ${ }^{52}$ not only provides the

50 Jordan J. Paust, "The Reach of ICC Jurisdiction over Non-Signatory Nationals," Vanderbilt Journal of Transnational Law, Vol. 33, No. 1 (2000), pp. 3-5.

51 Article 31 of the VCLT, entitled "General rule of interpretation", declares the following:

1 A treaty shall be interpreted in good faith in accordance with the ordinary meaning to be given to the terms of the treaty in their context and in the light of its object and purpose.

2 The context for the purpose of the interpretation of a treaty shall comprise, in addition to the text, including its preamble and annexes:

(a) any agreement relating to the treaty which was made between all the parties in connexion with the conclusion of the treaty;

(b) any instrument which was made by one or more parties in connexion with the conclusion of the treaty and accepted by the other parties as an instrument related to the treaty.

3 There shall be taken into account, together with the context:

(a) any subsequent agreement between the parties regarding the interpretation of the treaty or the application of its provisions;

(b) any subsequent practice in the application of the treaty which establishes the agreement of the parties regarding its interpretation;

(c) any relevant rules of international law applicable in the relations between the parties.

4 A special meaning shall be given to a term if it is established that the parties so intended.

52 The relevant parts of the preamble, which Paust quotes, reads as follows:

Affirming that the most serious crimes of concern to the international community as a whole must not 
Journal of International Relations and Comparative Culture Vol. 17 No. 1

"context" but also indicates the "object and purpose", and moreover that rules of customary international law concerning the first issue is "relevant rules of international law applicable in the relations between the parties" ${ }^{153}$. Additionally, with regard to "the preparatory work of the treaty and the circumstances of its conclusion" mentioned in Article 32 of the $\mathrm{VCLT}^{54}$, he does not closely examine the preparatory work of the Statute and simply assumes that it is not instrumental in interpreting the Statute, on the basis of the insufficiency of time at the Rome Conference ${ }^{55}$.

\section{Arguments against the Exercise of State Jurisdiction through the ICC}

Contrary to the scholars referred to in the previous subsections, a number of other academics deny the possibility of exercising state jurisdiction through the ICC. Among them, Ruth Wedgwood considers only the cases of the territorial state's acceptance. On the other hand, Madeline Morris, and Lee Casey and David Rivkin, Jr. consider all the cases of the ICC's exercise of jurisdiction, while offering arguments against the exercise of state jurisdiction through the ICC only in relation to the cases of the territorial state's acceptance ${ }^{56}$. These scholars explore the following two issues to support their view.

The first is whether states can exercise, under customary international law, territorial and/or universal jurisdictions over the crimes with respect to which the ICC has jurisdiction in accordance with the Statute. Casey and Rivkin, Jr. point out that even territorial jurisdiction cannot be exercised in some cases due to jurisdictional immunity, referring to several pieces of evidence such as the judgement of the International Court of Justice (hereinafter referred to as "the ICJ") on the Case Concerning the Arrest

go unpunished and that their effective prosecution must be ensured by taking measures at the national level and by enhancing international cooperation,

Determined to put an end to impunity for the perpetrators of these crimes [...],

Recalling that it is the duty of every State to exercise its criminal jurisdiction over those responsible for international crimes,

$[\ldots]$

Determined to these ends [...] to establish an independent permanent International Criminal Court [...] with jurisdiction over the most serious crimes of concern to the international community as a whole,

53 Paust, supra note 50, pp. 5-8.

54 Article 32 of the VCLT, entitled "Supplementary means of interpretation", declares the following:

Recourse may be had to supplementary means of interpretation, including the preparatory work of the treaty and the circumstances of its conclusion, in order to confirm the meaning resulting from the application of article 31 , or to determine the meaning when the interpretation according to article 31 :

(a) leaves the meaning ambiguous or obscure; or

(b) leads to a result which is manifestly absurd or unreasonable.

55 Paust, supra note 50, p. 6.

56 For the arguments which Morris and Casey and Rivkin, Jr. offer in relation to the other cases, see section 2 of this chapter. 
The Legal Basis for the Exercise of Jurisdiction

Warrant of 11 April 2000 (hereinafter referred to as "the Arrest Warrant Case") $(2002)^{57,58}$. Moreover, Wedgwood, Morris, and Casey and Rivkin, Jr. claim that universal jurisdiction cannot be exercised under customary international law with respect to at least some of the crimes under the Statute ${ }^{59}$.

The second issue is whether territorial and/or universal jurisdictions of states can be exercised, under customary international law, through courts, including the ICC, other than their own domestic ones when they give consent (including consent given in accordance with Article 25 of the UN Charter). All of the scholars in this category share a negative view, arguing that there is no relevant preceding mechanism of such exercise of state jurisdiction. Firstly, Wedgwood asserts that universal jurisdiction contained in some treaties like the Hague Hijacking Convention ${ }^{60}$ "has generally been exercised among treaty parties and only for national courts", and also points out that the ECHR "does not exercise criminal jurisdiction, and exercises its jurisdiction only among treaty parties" ${ }^{\prime \prime 1}$. Secondly, Morris claims that the exercise of jurisdiction by the

57 The relevant part of the judgement reads as follows:

The Court would observe at the outset that in international law it is firmly established that, as also diplomatic and consular agents, certain holders of high-ranking office in a State, such as the Head of State, Head of Government and Minister for Foreign Affairs, enjoy immunities from jurisdiction in other States, both civil and criminal. (Arrest Warrant of 11 April 2000 (Democratic Republic of the Congo $v$. Belgium), Judgment, I.C.J. Reports 2002, pp. 20-21, para. 51)

58 Lee A. Casey and David B. Rivkin, Jr., "The Limits of Legitimacy: The Rome Statute's Unlawful Application to Non-State Parties," Virginia Journal of International Law, Vol. 44, No. 1 (2003), pp. 79-84.

59 Ruth Wedgwood, "The International Criminal Court: An American View," European Journal of International Law, Vol. 10, No. 1 (1999), pp. 99-100; Madeline Morris, "High Crimes and Misconceptions: the ICC and Non-Party States," Law and Contemporary Problems, Vol. 64, No. 1 (2001), pp. 28-29; Casey and Rivkin, Jr., supra note 58, pp. 75-79.

Although this paper does not elaborate on universal jurisdiction of states at length (see note 38), it is necessary to take note of the following argument which is relevant to its conception. Mitsue Inazumi claims that it is doubtful whether universal jurisdiction can be exercised under customary international law by states which do not keep an alleged offender in custody, referring to President Guillaume's separate opinion attached to the judgment on the Arrest Warrant Case. Mitsue Inazumi, "The Meaning of the State Consent Precondition in Article 12 (2) of the Rome Statute of the International Criminal Court: A Theoretical Analysis of the Source of International Criminal Jurisdiction," Netherlands International Law Review, Vol. 49, Iss. 2 (2002), pp. 189-190. The relevant part of the separate opinion reads as follows:

$[\mathrm{N}]$ one of these texts [=the texts of the Hague Hijacking Convention and the like] has contemplated establishing jurisdiction over offences committed abroad by foreigners against foreigners when the perpetrator is not present in the territory of the State in question. Universal jurisdiction in absentia is unknown to international conventional law. (Separate Opinion of President Guillaume, I.C.J. Reports 2002, pp. 39-40, para. 9)

However, with regard to the legal basis for the ICC's exercise of jurisdiction, Inazumi does not provide a sufficiently clear theoretical framework. Inazumi, supra note 59, pp. 184-192.

60 See note 31 .

61 Wedgwood, supra note 59, pp. 99-100. The assertion quoted here is also relevant to the first issue, i.e. whether universal jurisdiction can be exercised under customary international law with respect to the crimes under the Statute. 
Journal of International Relations and Comparative Culture Vol. 17 No. 1

IMT, International Military Tribunal for the Far East (hereinafter referred to as "the IMTFE", ICTY and ICTR is based on the consent of nationality states (including consent given in accordance with Article 25 of the UN Charter ${ }^{62,63}$, and also concludes, from the text and the preparatory work of the Genocide and Apartheid Conventions, that the legal basis for the exercise of jurisdiction by the international penal tribunals contained therein has not been decided ${ }^{64}$. Lastly, Casey and Rivkin, Jr. contend that servants of the British East India Company (hereinafter referred to as "the BEIC") were acting as "deputies" of the Moghul Emperor in connection with the BEIC's exercise of jurisdiction in India, and also assert that Western powers could not exercise jurisdiction in the Ottoman Empire or China over nationals of a state non-party to the relevant agreement on jurisdiction unless the non-party state gave consent ${ }^{65}$.

Moreover, it can be pointed out that while, as already mentioned, all of the scholars in this category offer arguments against the exercise of state jurisdiction through the ICC only in relation to the cases of the territorial state's acceptance, their arguments concerning the first issue can also deny the possibility of exercising universal jurisdiction of states through the ICC in other cases, and their arguments concerning the second issue can also deny the possibility of exercising any kind of state jurisdiction in other cases $^{66}$.

\section{Summary of Section 1}

This section has examined the arguments presented by some scholars who regard (part of) the ICC's exercise of jurisdiction as the exercise of state jurisdiction through the ICC, and the counter-arguments presented by others who deny the possibility of such exercise of state jurisdiction. When setting aside their differences as to what kind

62 It can be pointed out that the theoretical framework described here is the same as the one which Morris uses to explain the ICC's exercise of jurisdiction in the cases of the nationality state's acceptance or Security Council's referral. For further details, see section 2 of this chapter.

63 However, Morris also views the IMT as a domestic court rather than an international one, arguing that "[a] more robust, and perhaps more accurate, reading would be that the Nuremberg tribunal prosecutions were actually an exercise of national jurisdiction by the effective German sovereign, the Allies". Morris, supra note 59, pp. 38, 40. On the other hand, as regards the IMTFE, she contends that the Japanese government "at least formally, retained sovereign power in Japan after the war". Ibid., p. 37.

In addition, as regards the ICTY, Morris admits that the ICTY cannot exercise jurisdiction over nationals of the FRY legally if the FRY was not a member of the UN and moreover the UN Charter does not bind non-party states. Ibid., p. 36.

64 Ibid., pp. 35-45.

65 Casey and Rivkin, Jr., supra note 58, pp. 85-88.

66 However, to be more precise, it should be added that Wedgwood's assertion about universal jurisdiction contained in some treaties can only deny the possibility of exercising this kind of state jurisdiction through the ICC in other cases. 
The Legal Basis for the Exercise of Jurisdiction

of state jurisdiction can or cannot be exercised through the ICC, it can be said that any of their contentions is related to one of the following three issues: 1) Whether states can exercise, under customary international law, a kind of state jurisdiction over the crimes with respect to which the ICC has jurisdiction in accordance with the Statute. 2) Whether a kind of state jurisdiction can be exercised, under customary international law, through courts, including the ICC, other than their own domestic ones when they give consent (including consent given in accordance with Article 25 of the UN Charter). 3) Whether Article 12 of the Statute provides for the obligation of accepting states to acquiesce in the ICC's exercise of jurisdiction as the exercise of a kind of their state jurisdiction through the ICC, and whether an acceptance in accordance with the same article constitutes consent to the creation of the above-mentioned obligation.

In order to confirm that (part of) the ICC's exercise of jurisdiction can be regarded as the exercise of a kind of state jurisdiction through the ICC, it is necessary to demonstrate that all of the three issues mentioned above can be answered in the affirmative. However, there seems to be no scholar who carries out such an attempt ${ }^{67}$. In particular there does not seem to be anyone but Paust who addresses the third issue, though it may be assumed that other scholars who argue for the exercise of state jurisdiction through the ICC also (subconsciously) interpret Article 12 of the Statute according to their opinions on what kind of state jurisdiction is exercised through the $\mathrm{ICC}^{68}$.

In addition, it can be pointed out that if the arguments in subsections 2 or 4 are valid, the conditions of the ICC's exercise of jurisdiction described in the Statute (i.e. the territorial state's acceptance, nationality state's acceptance and UN Security Council's referral) are found to be irrelevant to the legality of the ICC's exercise of jurisdiction. This is because if that is the case, 60 states had become parties to the Statute and

67 As stated in its introduction, this chapter only mentions the scholars who provide sufficiently clear theoretical frameworks. So, it does not refer to scholars who regard (part of) the ICC's exercise of jurisdiction as the exercise of state jurisdiction through the ICC but do not attempt any demonstration.

68 However, to be more precise, it should be added that Arnaut, who cites preceding mechanisms of the exercise of state jurisdiction through international courts and claims that both territorial and universal jurisdictions of the territorial state are exercised through the ICC, seems to think as follows: Article 12 of the Statute provides for the obligation of accepting states to acquiesce in the ICC's exercise of jurisdiction as the exercise of their state jurisdiction in general through the ICC, and an acceptance in accordance with the same article constitutes consent to the creation of the above-mentioned obligation.

Moreover, it should also be added that other scholars who consider only the cases of the territorial state's acceptance may also regard the ICC's exercise of jurisdiction in the cases of the nationality state's acceptance as the exercise of active personality jurisdiction (and universal jurisdiction in Scharf's argument) of accepting states through the ICC. And if this is the case, Article 12 of the Statute is interpreted accordingly. 
Journal of International Relations and Comparative Culture Vol. 17 No. 1

accepted the ICC's exercise of jurisdiction by its entry into force ${ }^{69}$, which means that they had given consent to the creation of their obligation to acquiesce in the ICC's exercise of jurisdiction as the exercise of their (territorial jurisdiction and) universal jurisdiction through the $\mathrm{ICC}^{70}$.

On the contrary, in order to deny the possibility of exercising state jurisdiction through the ICC, it is sufficient to demonstrate that one of the three issues mentioned above can be answered in the negative. Thus, the fact that none of the scholars referred to in subsection 5 deals with the third issue does not mean that their arguments are insufficient.

69 See Article 12, paragraph 1 (see section 1 of chapter 1) and Article 126 of the Statute. The latter article entitled "Entry into force" declares the following:

1 This Statute shall enter into force on the first day of the month after the 60th day following the date of the deposit of the 60th instrument of ratification, acceptance, approval or accession with the Secretary-General of the United Nations.

2 For each State ratifying, accepting, approving or acceding to this Statute after the deposit of the 60th instrument of ratification, acceptance, approval or accession, the Statute shall enter into force on the first day of the month after the 60th day following the deposit by such State of its instrument of ratification, acceptance, approval or accession.

70 The scholars referred to in subsections 2 and 4 assume that all states can exercise universal jurisdiction at any time. On the other hand, for the view that it can be exercised only by the custodial state, see note 59 . If this view is valid, only the custodial state's acceptance is relevant to the legality of the ICC's exercise of jurisdiction, which means that the analysis given here is baseless. 